\title{
PLANT ARCHITECTURE OF PASPALUM VAGINATUM SCHWARTZ MODIFIED BY NITRATE AND AMMONIUM NUTRITION ${ }^{1}$
}

\author{
JOSÉ BELTRANO ${ }^{2}$, MARTA GUILLERMINA RONCO ${ }^{3}$, ROBERTO BARREIRO ${ }^{4}$ and EDGARDO RAÚL MONTALDI ${ }^{5}$
}

\begin{abstract}
Paspalum vaginatum Schwartz plants were grown under greenhouse conditions in a continuous-flow hydroponic culture, containing $\mathrm{NO}_{3}^{-}$or $\mathrm{NH}_{4}^{+}$or $\mathrm{NH}_{4} \mathrm{NO}_{3}$ as nitrogen source. After 30 days, the size of aerial biomass and root system decreased significantly when plants were supplied with $\mathrm{NH}_{4}^{+}$as exclusive nitrogen source. Compared to $\mathrm{NO}_{3}^{-}$treatment, reducing and non-reducing sugars were decreasing together with a significant increase in amino acids content. $\mathrm{NH}_{4}^{+}$-nutrition caused tillers to grow toward an orthogravitropic position (average angle of $68^{\circ}$ with respect to the horizontal), and with $\mathrm{NO}_{3}^{-}$-nutrition, tillers tended to become diagravitropic (average angle of $23^{\circ}$ ). With $\mathrm{NH}_{4} \mathrm{NO}_{3}$ all the parameters measured had values in between those of the other two sources. Thus, the morphologic differences among plants growing in $\mathrm{NO}_{3}^{-}$or $\mathrm{NH}_{4}^{+}$nutrition confirm the hypothesis that nitrogen source determines the growth habit of tillers in $P$. vaginatum by modulating the endogenous levels of reducing-non-reducing sugars.
\end{abstract}

Index terms: nitrogen source, orthogravitropism, diagravitropism, sucrose.

\section{A ARQUITETURA DE PASPALUM VAGINATUM SCHWARTZ MODIFICADA PELA NUTRIÇÃO DE NITRATO E AMÔNIO}

\begin{abstract}
RESUMO - Plantas de Paspalum vaginatum Schwartz foram cultivadas em casa de vegetação, em cultura hidropônica de fluxo contínuo, contendo $\mathrm{NO}_{3}^{-}, \mathrm{NH}_{4}^{+}$ou $\mathrm{NH}_{4} \mathrm{NO}_{3}$ como fontes exclusivas de nitrogênio. Após 30 dias, o peso da matéria seca da parte aérea e da raiz diminuiu significativamente quando as plantas receberam $\mathrm{NH}_{4}^{+}$. Comparando esse tratamento com $\mathrm{NO}_{3}^{-}$, ocorreu decréscimo no teor de açúcares redutores e não-redutores e aumento significativo no conteúdo de aminoácidos. A aplicação de $\mathrm{NH}_{4}^{+}$causou crescimento das hastes na direção ortogravitrópica (ângulo médio de $68^{\circ}$ em relação à horizontal), e nas plantas que receberam $\mathrm{NO}_{3}^{-}$, as hastes tendiam a tornar-se diagravitrópicas (ângulo médio de $23^{\circ}$ ). $\mathrm{Com} \mathrm{NH}_{4} \mathrm{NO}_{3}$, todos os parâmetros medidos apresentaram valores entre os das outras duas fontes. As diferenças morfológicas entre as plantas nutridas com $\mathrm{NO}_{3}^{-}$ou $\mathrm{NH}_{4}^{+}$confirmam a hipótese segundo a qual a fonte de nitrogênio determina o hábito de crescimento das hastes em Paspalum vaginatum ao regular os níveis endógenos dos açúcares redutores e não-redutores.
\end{abstract}

Termos para indexação: fonte de nitrogênio, ortogravitrópico, diagravitrópico, sucrose.

\footnotetext{
${ }^{1}$ Accepted for publication on February 26, 1999.

${ }^{2}$ Agronomist, Titular Prof. and Researcher, Comisión De Investigaciones Científicas (CIC-BA). Prov. Buenos Aires. Instituto de Fisiología Vegetal (INFIVE), UNLP. CC 327, 1900 La Plata, Argentina. E-mail: beltrano@isis.unlp.edu.ar

${ }^{3}$ Nat. Scien., Dr., Adjunct Prof. CIC-BA. INFIVE.

${ }^{4}$ Agronomist. INFIVE

${ }^{5}$ Agronomist. Superior Researcher, CONICET. INFIVE.
}

\section{INTRODUCTION}

The growth habit of grasses such as Cynodon dactylon, C. plectostachyum and Paspalum vaginatum is determined by their endogenous sucrose content. This means that high concentrations of non-reducing sugars determine the diagravitropic growth of tillers; moreover plants 
tested in environments that diminish their sucrose content, the growth habit of tillers tends to become orthotropics (Montaldi, 1969, 1970, 1973, 1974; Willemoës et al., 1988).

Gnanam et al. (1980) demonstrated that $\mathrm{NH}_{4}^{+}$ completely inhibits light activation of two enzymes of photosynthesis, resulting in an accumulation of photosynthetic PGA which is metabolized via pyruvate and Krebs cycle. This leads to an increase in the availability of carbon skeletons for amino acid biosynthesis. Ammonium ions that enter the plant must be immediately assimilated to avoid toxic effects on plant metabolism.

In higher plants, $\mathrm{NH}_{4}^{+}$enrichment increases the flow of newly fixed carbon into TCA-cycle intermediates and amino acids while decreasing the carbon flux into sucrose and starch (Elrifi \& Turpin, 1986). In seedling plants supplied with $\mathrm{NH}_{4}^{+}$, Goyal et al. (1982) and Mehrer \& Mohr (1989) observed that the carbohydrate reserves quickly disappeared, so that proteins and lipids are used as respiratory substrates.

Different forms of inorganic nitrogen elicit distinct morphogenic effects on plants (Aspinall, 1961; McIntyre, 1971, 1972; Betria \& Montaldi, 1976; Leakey et al., 1978; Montaldi et al., 1984) and also act as important regulators of photosynthetic carbon flow (Elrifi \& Turpin, 1986).

McIntyre (1965) found in plants of Agropiron repens that, by varying the nitrogen supply, it was possible to control the behavior of rhizome buds. In this regard the buds ceased growth at low nitrogen concentration, whereas at high nitrogen concentration, the buds grew out as branches.

Nitrogen supplied as $\mathrm{NH}_{4} \mathrm{NO}_{3}$ to the rhizomes of $A$. repens, attached to the parent plant, caused the apical bud to develop as a tiller instead of rhizomes (McIntyre, 1972). Moreover, rhizomes growing with low nitrogen supply showed higher carbohydrate content than those growing in a high supply. Montaldi (1970) has shown that $\mathrm{NH}_{4}^{+}$or urea opposed the morphogenic effect of sucrose on diagravitropism of C. dactylon .

In this work was tested the hypothesis that nitrogen nutrition determines the growth habit of tillers in $P$. vaginatum by modulating the endogenous concentrations of reducing-non-reducing sugars.

\section{MATERIAL AND METHODS}

\section{Plant material and growth condition}

Plants of $P$. vaginatum were obtained from phytomers (node with attached leaf, the subtending internode and the axillary bud) rooted on moist vermiculite in a growth chamber at $22 \pm 2{ }^{\circ} \mathrm{C}$. During 10 days pretreatment period, seedlings were grown into continuously aerated hydroponic culture units that received a half-strength nutrient solution containing $1.0 \mathrm{mM} \mathrm{NO}_{3}^{-}, 0.25 \mathrm{mM} \mathrm{H}_{2} \mathrm{PO}_{4}^{-}, 1.25 \mathrm{mM} \mathrm{K}^{+}$, $0.5 \mathrm{mM} \mathrm{SO}_{4}^{2-}, 0.25 \mathrm{mM} \mathrm{Ca}^{2+}, 0.25 \mathrm{mM} \mathrm{Mg}^{2+}, 19 \mathrm{mM} \mathrm{B}$, $7.2 \mathrm{mM} \mathrm{Cl}, 3.7 \mathrm{mM} \mathrm{Zn}, 0.13 \mathrm{mM} \mathrm{Cu}, 0.05 \mathrm{mM}$ Mo and $10 \mathrm{mM} \mathrm{Fe}$ as Fe-Sequestrene (Chaillou et al., 1994) (complete nutrient solution) until the start of the treatments. Seedlings with roots between 5 and $10 \mathrm{~cm}$ long were transferred into $200 \mathrm{~mL}$ tubes with continuously-flow hydroponic culture (1 plant per tube) and placed in opaque boxes to avoid the effect of light on roots.

The experiment consisted of four treatments on 12 plants each, arranged in a completely random design; the treatments were as follows: (a) Complete nutrient solution; (b) Complete nutrient solution (without $\mathrm{NO}_{3}^{-}$) containing $1.0 \mathrm{mM} \mathrm{NH}_{4}^{+}$, as $\mathrm{NH}_{4} \mathrm{Cl}$; (c) Complete nutrient solution (without $\mathrm{NO}_{3}^{-}$) containing $1.0 \mathrm{~mol} \mathrm{~m}^{-3} \mathrm{NH}_{4}^{+}$, as $\left(\mathrm{NH}_{4}\right)_{2} \mathrm{SO}_{4}$; (d) Complete nutrient solution containing $0.5 \mathrm{mM} \mathrm{NH}_{4}^{+}$plus $0.5 \mathrm{mM} \mathrm{NO}-$, as $\mathrm{NO}_{3} \mathrm{NH}_{4}$. Except for $\mathrm{SO}_{4}{ }^{2+}$, which was used as the variable ion, concentrations of other nutrients were the same for treatments solutions as for the pretreatment solution, and the $\mathrm{pH}$ was adjusted to 6.4 . The culture solution was replaced with fresh at 2-day intervals.

The plants were grown in a greenhouse with a photoperiod of 14 hours and day/night temperatures of $24 \pm 5 / 17 \pm 5^{\circ} \mathrm{C}$. The photosynthetic photon flux at plant height was about $1,400 \mu \mathrm{mol} \mathrm{m} \mathrm{m}^{-2} \mathrm{~s}^{-1}$, measured at noon with a Licor Li-1000 Data Logger.

The plants were grown for 4 weeks after starting the treatments.

\section{Measurements}

Plant parts were separated into shoots (stems and leaves) and roots. Shoots and roots were dried at $80^{\circ} \mathrm{C}$, 72 hours, for dry weight (DW). The number of tiller, stolons and internode stolon lengths were determined. Average tiller angle with respect to the horizontal was measured with a protractor.

Each sample (1 $\mathrm{g}$ fresh weight) was ground with mortar and pestle and extracted in $5 \mathrm{~mL}$ of methanol-chloroformwater $(\mathrm{MCW})$. Total amino acids were evaluated by the 
method of Yemm \& Cocking (1955). The method of Bradford (1976) was used for protein determinations using bovine serum albumin as the protein standard. Total nitrogen was measured by micro-Kjeldahl digestion and the $\mathrm{NH}_{4}^{+}$determined by the Nessler method, as described by Linder \& Harley (1942). Reducing and total sugars were analyzed by the Somogy method (Cronin \& Smith, 1979), in $95 \%$ (v/v) ethanol extracts. Respiration rates were measured in shoots, with a Gilson differential respirometer.

The effects of the different treatments were determined by analysis of variance (ANOVA). Differences among treatments means were analyzed by the LSD at 0.05 probability level.

\section{RESULTS AND DISCUSSION}

The aerial and root biomass showed a sharp reduction in plants treated with $\mathrm{NH}_{4}^{+}$, mostly by decreasing shoot growth compared to root growth. Plants suppling with $\mathrm{NH}_{4} \mathrm{Cl}$ and $\left(\mathrm{NH}_{4}\right)_{2} \mathrm{SO}_{4}$ decreased the shoot growth by $65 \%$ with respect to $\mathrm{NO}_{3}^{-}$, whereas, $\mathrm{NH}_{4} \mathrm{NO}_{3}$ decreased the shoot growth by $57 \%$. Roots growth decreased by $56 \%, 56 \%$ and $49 \%$, respectively (Fig. 1). In a young leaf, where

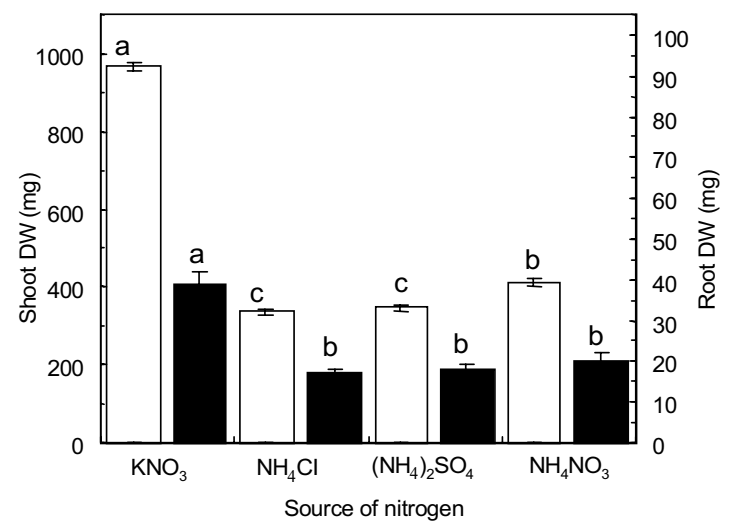

FIG. 1. Dry matter accumulation in shoot $\square$ and roots of $P$. vaginatum, when $1.0 \mathrm{mM} \mathrm{NO}_{3}^{-}$, $1.0 \mathrm{mM} \mathrm{NH}+\left(\right.$ as $\mathrm{NH}_{4} \mathrm{Cl}$ or $\left.\left(\mathrm{NH}_{4}\right)_{2} \mathrm{SO}_{4}\right)$ and $0.5 \mathrm{mM} \mathrm{NH}_{4}^{+}$plus $0.5 \mathrm{mM} \mathrm{NO} \mathrm{NO}_{3}^{-}$were supplied during 30 days. For each treatment values are means of 12 replicate plants. Vertical bars represent \pm SE. Bars with different letters differ significantly by LSD test, $P=0.05$. rapid photosynthesis occurs, $\mathrm{NO}_{3}^{-}$reduction consumes a large quantity of reducing power. In view of the increased requirements for photochemical energy in $\mathrm{NO}_{3}^{-}$reduction, one might expect $\mathrm{NH}_{4}^{+}-\mathrm{N}$ plants to grow better than $\mathrm{NO}_{3}^{-}-\mathrm{N}$ plants. However, the $\mathrm{NH}_{4}^{+}$-supplied plants generally exhibit less growth than $\mathrm{NO}_{3}^{-}-\mathrm{N}$ plants. Chaillou et al. (1994); Raab \& Terry (1994); Rideout et al. (1994), have also observed this detrimental effect of $\mathrm{NH}_{4}^{+}$compared to $\mathrm{NO}_{3}^{-}$nutrition in Beta vulgaris and in soybean. Other researchers have found that $\mathrm{NH}_{4}^{+}$nutrition decrease dry matter (Lewis \& Chadwick, 1983; Lindt \& Feller, 1987; Salsac et al., 1987; Ota et al., 1988; Lewis et al., 1989).

Fig. 2 shows that in our experiments dark respiration was $56 \%$ less in $\mathrm{NO}_{3}^{-}-\mathrm{N}$ plants than it was in $\mathrm{NH}_{4}^{+}-\mathrm{N}$ ones. Elrifi \& Turpin (1986) showed that $\mathrm{NH}_{4}^{+}$resulted in a large stimulation of dark respiration, so they proposed that the suppression of photosynthetic carbon fixation, in response to nitrogen supply, was the result of a competition for metabolites between the Calvin cycle and nitrogen assimilation. On the other hand, Gnanam et al (1980) and Giengenberger \& Stitt (1991) conclude that an

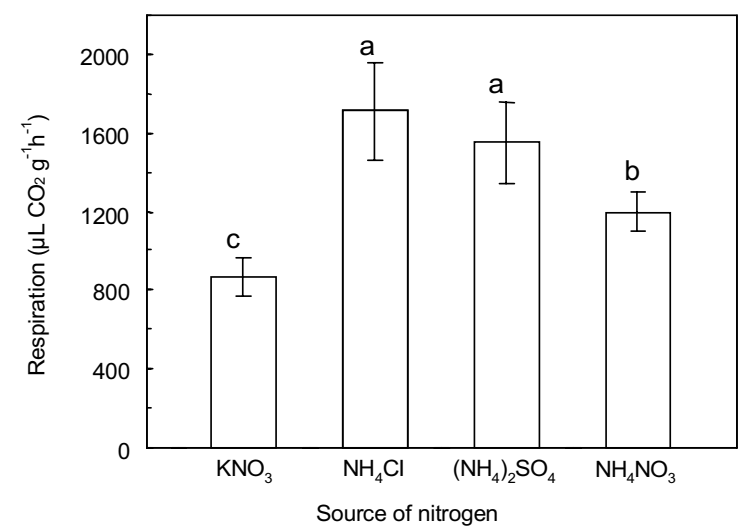

FIG. 2. Shoot respiration of $P$. vaginatum, when $1.0 \mathrm{mMNO}_{3}^{-}, 1.0 \mathrm{mM} \mathrm{NH}_{4}^{+}$as $\left(\mathrm{NH}_{4} \mathrm{Cl}\right.$ or $\left(\mathrm{NH}_{4}\right)_{2} \mathrm{SO}_{4}$ ) and $0.5 \mathrm{mM} \mathrm{NH}_{4}^{+}$plus 0.5 $\mathrm{mM} \mathrm{NO}_{3}^{-}$were supplied during 30 days. For each treatment values are means of 12 replicate plants. Vertical bars represent \pm SE. Bars with different letters differ significantly by LSD test, $P=\mathbf{0 . 0 5}$.

Pesq. agropec. bras., Brasília, v.34, n.7, p.1159-1166, jul. 1999 
increase in the respiration may be due to a faster turnover of pyruvate and Krebs cycle, so speeding up carbohydrate breakdown and, as a consequence, there are more carbon chains to form amino acids.

In our experiments $\mathrm{NH}_{4}^{+}-\mathrm{N}$ caused a significant increase in amino acids content $\left(80.29 \mu \mathrm{mol} \mathrm{g}^{-1} \mathrm{DW}\right)$ as compared with $\mathrm{NO}_{3}^{-}-\mathrm{N}$ plants $\left(33.17 \mu \mathrm{mol} \mathrm{g}{ }^{-1} \mathrm{DW}\right)$ (Fig. 3). Similar results were encountered in other species, that is the amino acids content was higher in $\mathrm{NH}_{4}^{+}-\mathrm{N}$ plants compared to $\mathrm{NO}_{3}^{-}-\mathrm{N}$ ones (Chaillou et al., 1986a,1986b; Rideout et al., 1994; Osaki et al., 1995). Our results are also consistent with those of Mohamed \& Gnanam (1977), Platt et al. (1977), Bassham et al. (1981) and Chaillou et al. (1986a) who proposed that $\mathrm{NH}_{4}^{+}$ion diverted the assimilated carbon mainly towards amino acids.

Although plants grew less under $\mathrm{NH}_{4}^{+}$than in $\mathrm{NO}_{3}^{-}$solution, their leaves accumulated nitrogen at almost equal rate. Fig. 4 shows no significant differences in the total nitrogen content. On the other hand, $\mathrm{NH}_{4}^{+}-\mathrm{N}$ supply increased the synthesis of soluble protein (Fig. 3). These results agree with those of Raab \& Terry (1994), who found that soluble leaf

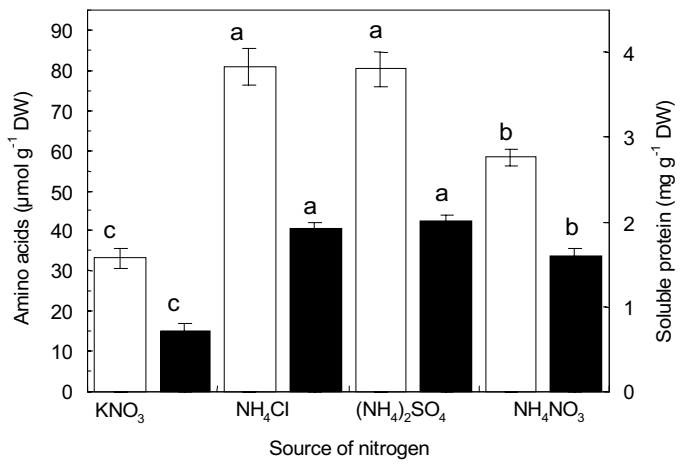

FIG. 3. Total amino acids $\square$ and soluble protein in shoots of $P$. vaginatum, when $1.0 \mathrm{mMNO}_{\overline{3}}, 1.0 \mathrm{mM} \mathrm{NH}_{4}^{+}$(as $\mathrm{NH}_{4} \mathrm{Cl}$ or $\left(\mathrm{NH}_{4}\right)_{2} \mathrm{SO}_{4}$ ) and $0.5 \mathrm{mM} \mathrm{NH}_{4}^{+}$plus $0.5 \mathrm{mM}$ $\mathrm{NO}_{3}^{-}$were supplied during 30 days. For each treatment values are means of 12 replicate plants. Vertical bars represent \pm SE. Bars with different letters differ significantly by LSD test, $\mathbf{P}=\mathbf{0 . 0 5}$. protein increased significantly in $\mathrm{NH}_{4}^{+}-\mathrm{N}$ plants compared to $\mathrm{NO}_{3}^{-}-\mathrm{N}$.

In the experiments of this work, plants treated with $\mathrm{NH}_{4}^{+}$, as exclusive nitrogen source, showed lower level of total sugars $(8.13 \%$ shoot DW) than those treated with $\mathrm{NO}_{3}^{-}(11.30 \%$ shoot DW) (Fig. 4). The rapid assimilation of $\mathrm{NH}_{4}^{+}$in glutamine led to a consumption of carbon skeletons, causing depletion of the foliar starch, sucrose and maltose (Raab \& Terry, 1995), likewise Mehrer \& Mohr (1989) concluded that the consumption of fixed carbon during the assimilation of $\mathrm{NH}_{4}^{+}$could appreciably reduce carbohydrates storage. Also with $\mathrm{NH}_{4}^{+}-\mathrm{N}$ supply, the endogenous content of nonreducing sugars decreased significantly, the Fig. 5 shows that the accumulation of non-reducing sugars was substantially less than in $\mathrm{NO}_{3}^{-}$-fed plants (1.04\% DW and $2.87 \%$ DW, respectively). Raab \& Terry (1994) showed that $\mathrm{NO}_{3}^{-}-\mathrm{N}$ plants had higher activities of sucrose synthase than $\mathrm{NH}_{4}^{+}-\mathrm{N}$ plants, in the latter system the activity of acid invertase doubled that of $\mathrm{NO}_{3}^{-}-\mathrm{N}$ plants.

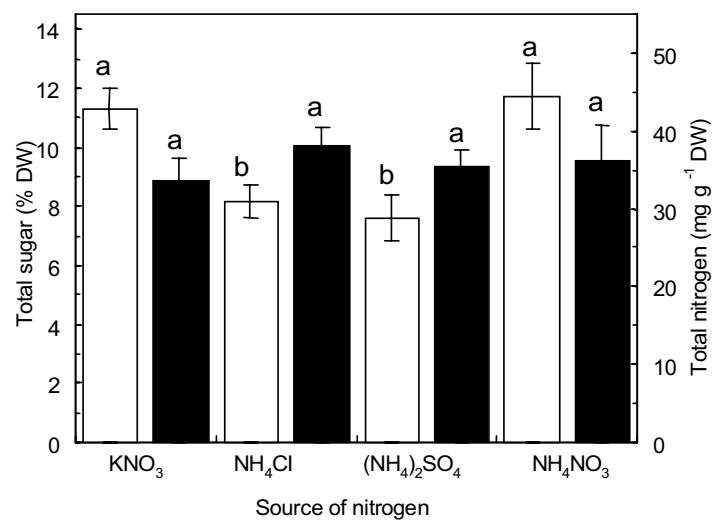

FIG. 4. Total sugar $\square$ and total nitrogen $\square$ in shoots of $P$. vaginatum, when $1.0 \mathrm{mM} \mathrm{NO}_{3}^{-}$, $1.0 \mathrm{mM} \mathrm{NH} \mathrm{NH}_{4}^{+}$(as $\mathrm{NH}_{4} \mathrm{Cl}$ or $\left.\left(\mathrm{NH}_{4}\right)_{2} \mathrm{SO}_{4}\right)$ and $0.5 \mathrm{mM} \mathrm{NH}_{4}^{+}$plus $0.5 \mathrm{mM} \mathrm{NO}_{\overline{3}}^{-}$were supplied during 30 days. For each treatment values are means of 12 replicate plants. Vertical bars represent \pm SE. Bars with different letters differ significantly by LSD test, $\mathbf{P}=\mathbf{0 . 0 5}$. 
The decrease in non-reducing sugars content with $\mathrm{NH}_{4}^{+}-\mathrm{N}$ treatment caused the tillers to grow tending toward an orthogravitropic position $\left(\mathrm{NH}_{4} \mathrm{Cl}=68^{\circ} ;\left(\mathrm{NH}_{4}\right)_{2} \mathrm{SO}_{4}=45^{\circ}\right)$ with longer internodes (18.9 and $19.5 \mathrm{~mm}$, respectively) and less stolons. On the other hand, plants treated with $\mathrm{NO}_{3}^{-}-\mathrm{N}$ that reached a higher content of endogenous non-reducing sugar, their tillers tended to become diagravitropic $\left(23^{\circ}\right)$, with shorter internodes $(11.3 \mathrm{~mm})$, and a significant increase in the stolon number per plant $\left(2.91, \mathrm{NO}_{3}^{-}-\mathrm{N}\right.$ versus 0.45 , $\mathrm{NH}_{4}^{+}-\mathrm{N}$ ) (Figs. 6 and 7).

The lower sucrose content of erect shoots of $\mathrm{NH}_{4}^{+}-\mathrm{N}$ plants, as compared with prostrate stolon of $\mathrm{NO}_{3}^{-}-\mathrm{N}$ plants, is consistent with the hypothesis that the nitrogen nutrition and endogenous levels of reducing-non-reducing sugar determine the growth habit of tiller in $P$. vaginatum. Therefore, the canopy architecture of plants supplied with $\mathrm{NO}_{3}^{-}$was strikingly different from that of plants treated with $\mathrm{NH}_{4}^{+}$(Fig. 8). Morphogenic differences among plants as a consequence of different nitrogen sources, result from a variation in the orthogravitropic/diagravitropic ratio of the tiller growth, the length of internodes and the growth angles of shoots and stolons with respect to the horizontal. Those characteristics were found also in C. dactylon by Montaldi $(1970,1974)$

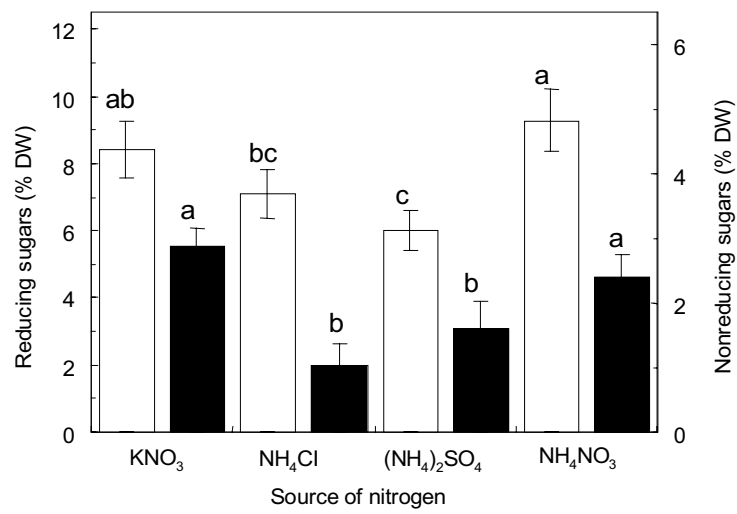

FIG. 5. Reducing sugars $\square$ and nonreducing sugars in shoots of $P$. vaginatum, when $1.0 \mathrm{mM} \mathrm{NO}-1.0 \mathrm{mM} \mathrm{NH}_{4}^{+}$(as $\mathrm{NH}_{4} \mathrm{Cl}$ or $\left.\left(\mathrm{NH}_{4}\right)_{2} \mathrm{SO}_{4}\right)$ and $0.5 \mathrm{mM} \mathrm{NH}_{4}^{+}$plus $0.5 \mathrm{mM}$ $\mathrm{NO}_{3}^{-}$were supplied during 30 days. For each treatment values are means of 12 replicate plants. Vertical bars represent \pm SE. Bars with different letters differ significantly by LSD test, $\mathbf{P}=\mathbf{0 . 0 5}$. and in $P$. vaginatum by Willemoës et al. (1988). Moreover, in agreement with Kojima \& Sonoike (1985) and Osaki et al. (1995), it was found that the nitrogen form affects the development and growth pattern of the plant.

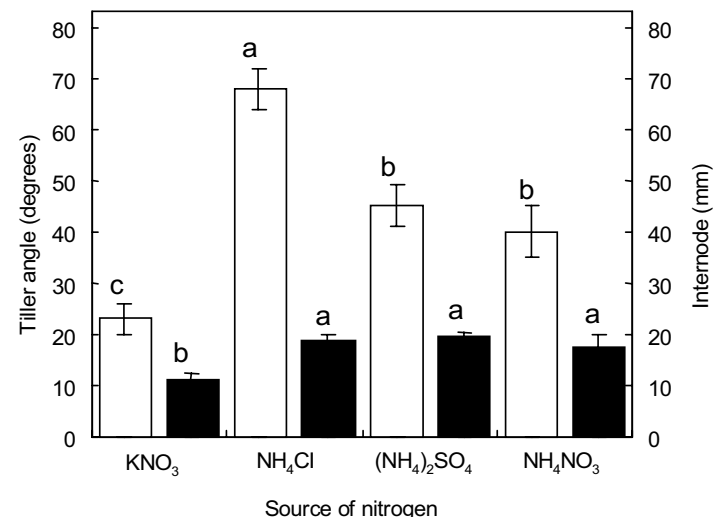

FIG. 6. Average tiller angle the horizontal $\square$ and internodes lenght of $P$. vaginatum, when $1.0 \mathrm{mM} \mathrm{NO}-, 1.0 \mathrm{mM} \mathrm{NH}_{4}^{+}$(as $\mathrm{NH}_{4} \mathrm{Cl}$ or $\left(\mathrm{NH}_{4}\right)_{2} \mathrm{SO}_{4}$ ) and $0.5 \mathrm{mM} \mathrm{NH} \mathrm{NH}_{4}^{+}$plus $0.5 \mathrm{mM}$ $\mathrm{NO}_{3}^{-}$were supplied during 30 days. For each treatment values are means of 12 replicate plants. Vertical bars represent \pm SE. Bars with different letters differ significantly by LSD test, $P=0.05$.

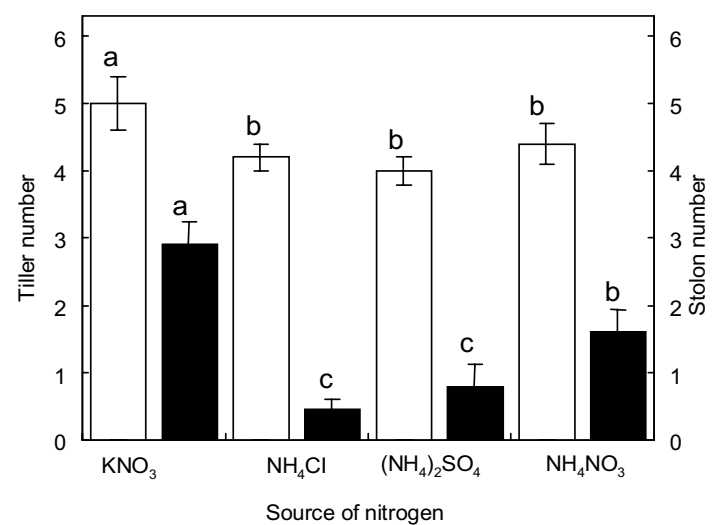

FIG. 7. Tiller number $\square$ and stolon number $\square$ of $P$. vaginatum, when $1.0 \mathrm{mM} \mathrm{NO}$,

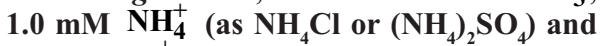
$0.5 \mathrm{mM} \mathrm{NH}_{4}^{+}$plus $0.5 \mathrm{mM} \mathrm{NO}-\mathrm{Nere} \mathrm{supplied}_{3}^{-}$we during 30 days. For each treatment values are means of 12 replicate plants. Vertical bars represent \pm SE. Bars with different letters differ significantly by LSD test, $\mathbf{P}=\mathbf{0 . 0 5}$.

Pesq. agropec. bras., Brasília, v.34, n.7, p.1159-1166, jul. 1999 


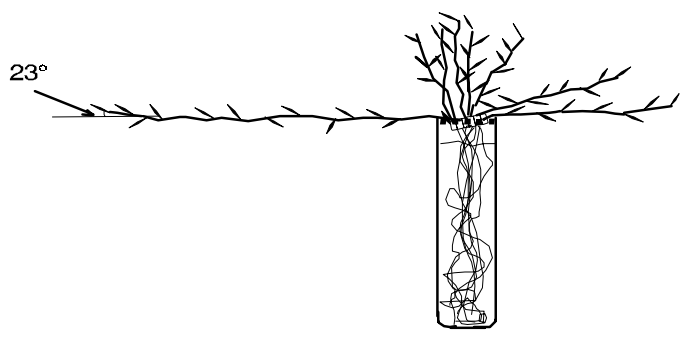

A

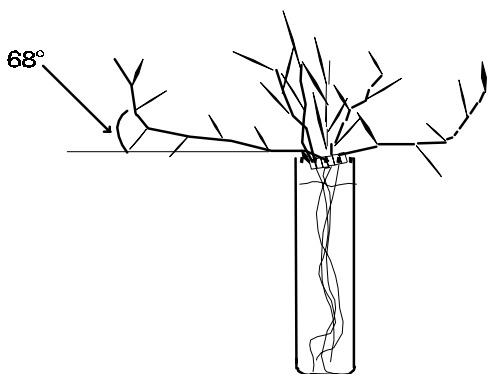

国

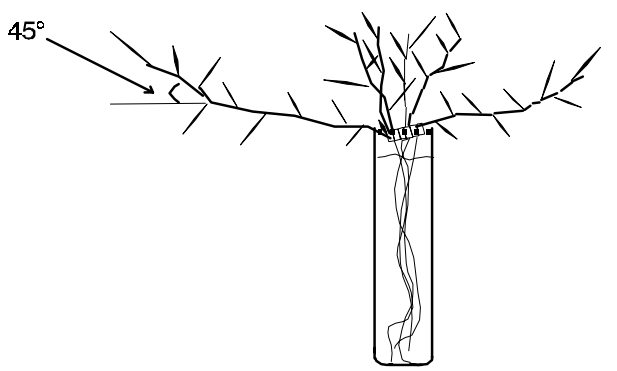

[C]

FIG. 8. Seedling scheme of $P$. vaginatum, 30 days old, illustrating the effects of the nitrogen supply on plant architecture (i.e. tiller angle, internode lenght and stolon number).

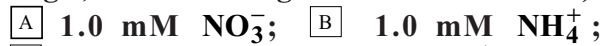
C $0.5 \mathrm{mM} \mathrm{NO} \mathrm{NO}_{3}^{-}$plus $0.5 \mathrm{mM} \mathrm{NH}$.

\section{CONCLUSIONS}

1. The morphogenic impact of different nitrogen sources absorbed by $P$. vaginatum results from changes in the endogenous sucrose content.

2. Such changes determine the plant architecture, modifying the orthogravitropic/diagravitropic ratio of tiller growth.

\section{REFERENCES}

ASPINAL, D. The control of tillering in the barley plant. I. The pattern of tillering and its relation to nutrient supply. Australian Journal of Biological Science, v.14, p.493-505, 1961.

BASSHAM, J.A.; LARSEN, P.O.; LAWYER, A.L.; CORWELL, K.L. Relationships between nitrogen metabolism and photosynthesis. In: BEWLEY, J.D. (Ed.). Nitrogen and carbon metabolism. London: Junk, 1981. p.35-163.

BETRIA, A.; MONTALDI, E.R. Efecto del nitrato de amonio y del ácido giberélico sobre la brotación del cípero (Cyperus rotundus L.). Revista de la Facultad de Agronomía, La Plata, v.52, p.21-30, 1976.

BRADFORD, M.M. A rapid and sensitive method for the quantitation of microgram quantities of protein utilizing the principle of protein-dye binding. Analytical Biochemistry, v.72, p.248-274, 1976.

CHAILLOU, S.; MOROT-GAUDRY, J.F.; SALSAC, L.; LESAINT, C.; JOLIVET, E. Compared effects of $\mathrm{NO}_{3}^{-}$and $\mathrm{NH}_{4}^{+}$on growth and metabolism of French bean. Physiologia Plantarum, v.24, p.679-871, 1986a.

CHAILLOU, S.; MOROT-GAUDRY, J.F.; SALSAC, L.; LESAINT, C.; JOLIVET, E. Nitrate and ammonium nutrition in french bean. Plant and Soil, v.91, p.363$365,1986 b$.

CHAILLOU, S.; RIDEOUT, J.W.; RAPER JUNIOR, C.D.; MOROT-GAUDRY, J.F. Responses of soybean to ammonium and nitrate supplied in combination to the whole root system or separately in a split-root system. Physiologia Plantarum, v.90, p.259-268, 1994.

CRONIN, D.A.; SMITH, S. A simple and rapid procedure for the analysis of reducing, total and individual sugars in potatoes. Potatoes Research, v.22, p.99-105, 1979.

ELRIFI, J.R.; TURPIN, D.H. Nitrate and ammonium induced photosynthetic suppression in N-limited Seleastrum minutum. Plant Physiology, v.81, p.273279, 1986.

GIENGENBERGER, P.; STITT, M. Regulation of carbon partitioning between sucrose and nitrogen assimilation in cotyledons of germinating Ricinus communis L. Seedlings. Planta, v.185, p.563-568, 1991. 
GNANAM, A.; MOHAMED, H.A.; SEETHA, R. Comparative studies on the effect of ammonia and blue light on the regulation of photosynthetic carbon metabolism in higher plants. The blue light syndrome. In: SENGER, H. (Ed.). The blue light syndrome. New York: Springer-Verlag, 1980. p.435-443.

GOYAL, S.S.; LORENZ, O.A.; HUFFAKER, R.C. Inhibitory effects of ammoniacal nitrogen on grown of radish plants. I. Characterization of toxic effects of $\mathrm{NH}_{4}^{+}$on growth and its alleviation by $\mathrm{NO}_{3}^{-}$. Journal of the American Society for Horticultural Science, v.107, p.125-129, 1982.

KOJIMA, S.; SONOIKE, K. The effect of the ammoniacal and nitrate nitrogen on the development of cucumber and rice plants and IAA content in shoots. Japanese Journal of Soil Science and Plant Nutrition, v.54, p.25-29, 1985

LEAKEY, R.R.B.; CHANCELLOR, R.J.; VINCE-PRUE, D. Regeneration from rhizome fragments of Agropyron repens (L.) Beauv. III. Effects of nitrogen and temperature on the development of dominance amongst shoots on multi-node fragments. Annals of Botany, v.42, p.197-204, 1978.

LEWIS, O.A.M.; CHADWICK, S. An ${ }^{15} \mathrm{~N}$ investigation into nitrogen assimilation in hydroponically-grown barley (Hordeum vulgare L. cv. Clipper) in response to nitrate, ammonium and mixed nitrate and ammonium nutrition. New Phytologist, v.95, p.635646, 1983.

LEWIS, O.A.M.; LEIDI, E.O.; LIPS, S.H. Effect of nitrogen source on growth response to salinity in maize and wheat. New Phytologist, v.111, p.1550$1560,1989$.

LINDER, R.C.; HARLEY, C.P. A rapid method for the determination of nitrogen in plants tissues. Science, v.96, p.565-566, 1942.

LINDT, T.; FELLER, U. Effect of nitrate and ammonium on long distance transport in cucumber plants. Botanica Helvetica, v.97, p.45-52, 1987.

McINTYRE, G.I. Apical dominance in the rhizomes of Agropyron repens (L.) Beauv. Some factors affecting the degree of dominance in isolated rhizomes. Canadian Journal of Botany, v.49, p.99-109, 1971.

McINTYRE, G.I. Some effects of the nitrogen supply on the growth and developmente of Agropyron repens L. Beauv. Weed Reasearch, v.5, p.1-12, 1965.
McINTYRE, G.I Studies on bud development in the rhizome of Agopyron repens. 2. The effect of nitrogen supply. Canadian Journal of Botany, v.50, p.393401, 1972.

MEHRER, Y.; MOHR, H. Ammonium toxicity: description of the syndrome in Sinapsis alba and the search for its causation. Physiologia Plantarum, v.77, p.545-554, 1989.

MOHAMED, A.H.; GNANAM, A. Regulation of photosynthetic carbon flow by ammonium ions in isolated bean leaf cell. Plant Biochemistry Journal, v.4, p.1-9, 1977.

MONTALDI, E.R. Cynodon dactylon: posible causa de su diageotropismo. Revista de Investigaciones Agropecuarias INTA. Argentina, Serie 2, v. 7, p. 67-87, 1970.

MONTALDI, E.R. Efecto de la sacarosa y otras sustancias sobre la forma de las hojas de Cynodon dactylon (L.) Revista de la Facultad de Agronomía, La Plata, v.50, p.61-71, 1974.

MONTALDI, E.R. Epinasty in Cynodon plectostachyum induced by sucrose and its reversion by gibberellic acid and nitrogen compounds. Experientia, v.29, p.1031-1032, 1973.

MONTALDI, E.R. Gibberellin-sugar interaction regulating the growth habit of bermudagrass (Cynodon dactylon L. (Pers.)). Experientia, v.25, p.91-92, 1969.

MONTALDI, E.R.; BELTRANO, J.; ABEDINI, W.; MARRONE, M.T. Factores que afectan la formación de rizomas en el sunchillo (Wedwlia glauca (Ort) Offm.). Revista de la Facultad de Agronomía de Buenos Aires, v.5, p.139-145, 1984.

OSAKI, M.; SHIRAI, J.; SHINANO, T.; TADANO, T. Effects of ammonium and nitrate assimilation on the growth and tuber swelling of potato plants. Soil Science of Plant Nutrition, v.41, p.709-719, 1995.

OTA, K.; TEZUKA, T.; YAMAMOTO, Y. Changes in Crassulacean acid metabolism of Kalanchoë blossfeldiana by different nitrogen sources. Plant Cell Physiology, v.29, p.533-537, 1988.

PLATT, S.G.; PLAUT, J.A.; BASSHAM, J.A. Ammonia regulation of carbon metabolism in photosynthesizing leaf discs. Plant Physiology, v.60, p.739-742, 1977.

RAAB, T.K.; TERRY, N. Carbon, nitrogen, and nutrient interactions in Beta vulgaris L. as influenced by nitrogen source, $\mathrm{NO}_{3}^{-}$versus $\mathrm{NH}_{4}^{+}$. Plant Physiology, v.107, p.575-584, 1995. 
RAAB, T.K.; TERRY, N. Nitrogen source regulation of growth and photosynthesis in Beta vulgaris L. Plant Physiology, v.105, p.1159-1166, 1994.

RIDEOUT, J.W.; CHAILLEOU, S.; RAPER JUNIOR, C.D.; MOROT-GAUDRY, J.F. Ammonium and nitrate uptake by soybean during recovery from nitrogen deprivation. Journal of Experimental Botany, v.45, p.23-33, 1994.

SALSAC, L.; CHAILLOU, S.; MOROT-GAUDRY, J.F.; LESAINT, C.; JOLIVET, E. Nitrite and ammonium nutrition in plants. Plant Physiology and Biochemistry, v.25, p.805-812, 1987.

WILLEMOËS, J.G.; BELTRANO, J.; MONTALDI, E.R. Diagravitropic growth promoted by higher sucrose contents in Paspalum vaginatum and its reversion by gibberellic acid. Canadian Journal of Botany, v.66, p.2035-2037, 1988.

YEMM, E.W.; COCKING, E.C. The determination of amino acids with ninhydrin. Analyst, Londom, v.80, p.209-213, 1955. 